(Hôpital St André, Bordeaux, France); Jean Marc Mauboussin, Claudine Barbuat, Isabelle Rouanet and Liliane Metge (Hôpital Carémeau, Nimes, France); and Jacques Reynes, Vincent le Moing, Jean-Marc Jacquet, Nadine Atoui, Mickael Loriette, David Morquin, Vincent Fauchere, Carine Favier, Corinne Merle, Vincent Baillat, Antoine da Silva, Rachid Mansouri, Christina Psomas, Sébastien Bommart, Hélène Kovacsik-Vernhet, Jean-Louis Pujol, Xavier Quantin and Maurice Hayot (Hôpital Gui de Chauliac, Montpellier, France).

This study was presented in part at the 21st Conference on Retrovirus and Opportunistic Infections in Boston, MA, USA, between March 3 and 6, 2014.:

We thank the trial participants, and the coordinators, engineers and technicians who made this study possible: Suzanne Izard, Jonathan Lalet, Amandine Cournil and Bruno Granouillac (UMI 233, IRD, University Montpellier 1, Montpellier, France).

\title{
References
}

1 Crothers K, Huang L, Goulet JL, et al. HIV infection and risk for incident pulmonary diseases in the combination antiretroviral therapy era. Am J Respir Crit Care Med 2010; 183: 388-395.

2 Madeddu G, Fois AG, Calia GM, et al. Chronic obstructive pulmonary disease: an emerging comorbidity in HIV-infected patients in the HAART era? Infection 2012; 41: 347-353.

3 Samperiz G, Guerrero D, Lopez M, et al. Prevalence of and risk factors for pulmonary abnormalities in HIV-infected patients treated with antiretroviral therapy. HIV Med 2014; 15: 321-329.

4 George MP, Kannass M, Huang L, et al. Respiratory symptoms and airway obstruction in HIV-infected subjects in the HAART era. PLoS One 2009; 4: e6328

5 Drummond MB, Kirk GD, Astemborski J, et al. Association between obstructive lung disease and markers of HIV infection in a high-risk cohort. Thorax 2012; 67: 309-314.

6 Morris A, Alexander T, Radhi S, et al. Airway obstruction is increased in pneumocystis-colonized human immunodeficiency virus-infected outpatients. J Clin Microbiol 2009; 47: 3773-3776.

7 Macintyre N, Crapo RO, Viegi G, et al. Standardisation of the single-breath determination of carbon monoxide uptake in the lung. Eur Respir J 2005; 26: 720-735.

8 Standardized lung function testing. Official statement of the European Respiratory Society. Eur Respir J 1993; 6 Suppl. 16:1-100

9 Global Initiative for Chronic Obstructive Lung Disease. Global Strategy for the Diagnosis, Management, and Prevention of Chronic Obstructive Pulmonary Disease. www.goldcopd.org/uploads/users/files/GOLD_Report_2014_ Jun11.pdf Date last updated: June 11, 2014.

10 Quanjer PH, Stanojevic S, Cole TJ, et al. Multi-ethnic reference values for spirometry for the 3-95-yr age range: the global lung function 2012 equations. Eur Respir J 2012; 40: 1324-1343.

11 Quanjer PH, Enright PL, Miller MR, et al. The need to change the method for defining mild airway obstruction. Eur Respir J 2011; 37: 720-722.

12 Buist AS, Vollmer WM, McBurnie MA. Worldwide burden of COPD in high- and low-income countries. Part I. The burden of obstructive lung disease (BOLD) initiative. Int J Tuberc Lung Dis 2008; 12: 703-708.

13 Hill K, Goldstein RS, Guyatt GH, et al. Prevalence and underdiagnosis of chronic obstructive pulmonary disease among patients at risk in primary care. CMAJ 2010; 182: 673-678.

14 Tashkin DP. Effects of marijuana smoking on the lung. Ann Am Thorac Soc 2013; 10: 239-247.

15 Fischer WA II, Drummond MB, Merlo CA, et al. Hepatitis C virus infection is not an independent risk factor for obstructive lung disease. COPD 2014; 11: 10-16.

16 Crothers K, McGinnis K, Kleerup E, et al. HIV infection is associated with reduced pulmonary diffusing capacity. J Acquir Immune Defic Syndr 2013; 64: 271-278.

17 Gingo MR, He J, Wittman C, et al. Contributors to diffusion impairment in HIV-infected persons. Eur Respir J 2013; 43: 195-203.

\section{Cladribine improves lung cysts and pulmonary function in a child with histiocytosis}

To the Editor:

Langerhans' cell histiocytosis $(\mathrm{LCH})$ is a rare disease of unknown aetiology involving accumulation of Langerhans' cells organised in granuloma, in various organs [1]. Pulmonary LCH (PLCH) is characterised by focal Langerhans' cell granulomas infiltrating and destroying distal bronchioles, which results in cysts, major destruction of the pulmonary tissue and pneumothorax [2,3]. PLCH is rare in children $<18$ years old.

When cysts are present, in children or adults, the disease is usually considered no longer active, and no treatment is effective for chronic cysts. The long-term outcome is marked by a slow progression to 

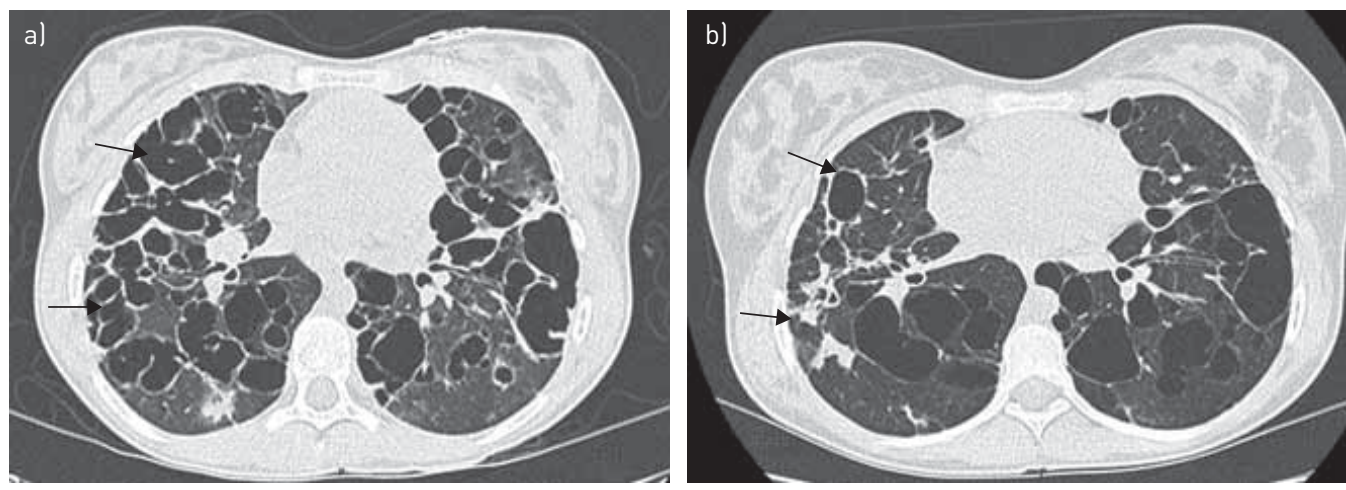

FIGURE 1 High-resolution computed tomography scans of the lung at the right inferior pulmonary vein in a child with primary Langerhans' cell histiocytosis a) before treatment with cladribine and b) 18 months after treatment. Lung cysts decreased in size or resolved (arrows). Resolved cysts appear as residual irregular-shaped pseudomasses.

respiratory insufficiency and may be an indication for lung transplantation [4]. Recently, cladribine (2-chlorodeoxyadenosine), a synthetic chlorinated deoxyadenosine analogue, was found to be effective in adult patients with chronic cystic PCLH, with improvement in both lung function and computed tomography (CT) findings $[5,6]$.

We report the case of a child with cystic PLCH included in the French LCH registry (UPN 2106223; www.histiocytose.org), who showed marked improvement with cladribine monotherapy.

The initial history of this patient was remarkable, and was reported in 2009 [7], because the first symptom was abnormal movement of the trunk at age 20 months. LCH was diagnosed by liver and skin biopsy, and the initial workup concluded liver (sclerosing cholangitis) and skin involvement, associated with fever and inflammatory syndrome. The LCH was treated with vinblastine, steroids and 6-mercaptopurine for 15 months (in addition to ursodesoxycholic acid), with complete remission.

2 months after the end of therapy, reactivation of the disease was diagnosed by mediastinal node and lung involvement. The lung involvement was limited to a few cysts, and vinblastine and steroids were resumed for 11 months. The outcome was again favourable and the lung cysts disappeared. 2 months after the end of therapy, pituitary involvement, with diabetes insipidus followed by thyroid insufficiency, with pituitary thickening, was observed. Hormone replacement therapy was given but not LCH-specific therapy. 18 months later, the patient presented a new reactivation localised to the lung, with bilateral pneumothorax. In addition to surgical cure of the pneumothorax, vinblastine and 6-mercaptopurine were resumed for 12 months, with no change in CT findings or clinical stability.

At 4 years and 9 months later, when the patient was 13 years old, reactivation of the disease was considered because she presented asthenia, weight loss (15\% loss in 6 months) and inflammatory syndrome. The lung condition had worsened to stage III World Health Organization (WHO) functional class dyspnoea and lung function had deteriorated (forced vital capacity (FVC): $0.65 \mathrm{~L}, 27 \%$ of predicted; forced expiratory volume in $1 \mathrm{~s}$ (FEV1): $0.45 \mathrm{~L}, 22 \%$ of predicted; FEV1/FVC: $81 \%$; and diffusing capacity of the lung for carbon monoxide: $1.05 \mathrm{mmol} \cdot \mathrm{min}^{-1} \cdot \mathrm{kPa}^{-1}, 45 \%$ of predicted). On $6-\mathrm{min}$ walk testing, the peripheral oxygen saturation decreased from $95 \%$ at rest to $89 \%$ after $330 \mathrm{~m}$ (40\% of predicted). High-resolution CT of the lung showed extensive thick-walled cysts, together with mediastinal nodes (fig. 1a). An increased erythrocyte sedimentation rate, of $70 \mathrm{~mm} \cdot \mathrm{h}^{-1}$ (normal value $<20 \mathrm{~mm} \cdot \mathrm{h}^{-1}$ ), was associated with decreased albuminaemia, $30 \mathrm{~g} \cdot \mathrm{L}^{-1}$ (normal value $>45 \mathrm{~g} \cdot \mathrm{L}^{-1}$ ).

Because of the previous therapy with vinblastine (for $\sim 4$ years in total) and its lack of efficacy for lung cysts, therapy with cladribine was considered. The patient received six courses of subcutaneous injections of cladribine at $5 \mathrm{mg} \cdot \mathrm{m}^{-2}$ each for five consecutive days every 4 weeks (cumulative dose $150 \mathrm{mg} \cdot \mathrm{m}^{-2}$ ) [1]. The treatment was well tolerated, with the exception of a febrile urticarial rash at the end of the therapy and 15 months later, an episode of genital infection due to herpes simplex virus type 2.

At 2 years and 6 months after the start of cladribine therapy, the dyspnoea had improved to WHO functional class II. High-resolution CT of the lung showed a decreased number of, or resolution of, thick-walled cysts, and the lung tissue initially containing these cysts had retracted. Resolved cysts appeared as residual irregular-shaped pseudomasses (fig. 1b). The cyst score (briefly, each lung was divided into three areas, from the lung apices to the domes of the diaphragm, and semi-quantitative CT scores were assigned to each area to estimate the extent of the cysts), from TAZI et al. [8], decreased from 22 in the pre-therapeutic evaluation to 18 at 2 years after therapy. FVC and FEV1 values increased by $53 \%$ 
$(+0.58 \mathrm{~L})$ and $55 \%(+0.40 \mathrm{~L})$, respectively, as compared with pretreatment values. On 6-min walk testing, the peripheral oxygen saturation decreased from $97 \%$ at rest to $94 \%$ after $481 \mathrm{~m}$ ( $76 \%$ of predicted).

This case shows, for the first time, the marked efficacy of cladribine treatment for clinical, functional and imaging outcomes in a nonsmoking child with PCLH. In children, PCLH usually occurs as part of disseminated LCH (multifocal and systemic forms), with pulmonary involvement often not a prominent feature [9]. The pathogenesis of PLCH in childhood differs from that of adults, in that more than 95\% of affected adults are cigarette smokers [3], and the pathology may reflect an uncontrolled immune response to an unknown stimulus or antigen.

Since the first publication reporting its use, in 1993 [10], cladribine has been used for several LCH patients $[11,12]$. However, the main indication is refractory disease, mainly bone lesions, and not lung-cyst LCH. To date, the lung has not been considered a target organ for cladribine in children, especially in disease with diffuse cystic lesions. Although further studies are warranted to confirm our results, the present observation gives promise for the use of cladribine in children with PCLH. child with PCLH http://ow.ly/CK3XJ

Ralph Epaud ${ }^{1-3}$, Hubert Ducou Le Pointe ${ }^{4,5}$, Sylvie Fasola ${ }^{6}$, Sandra Ploussard ${ }^{6}$, Celine Delestrain ${ }^{1,2}$, Chiara Sileo ${ }^{4,5}$ and Jean Donadieu ${ }^{6}$

${ }^{1}$ Centre Intercommunal de Créteil, Service de Pédiatrie, Créteil, France. ${ }^{2}$ Inserm, U955, Equipe 11, Créteil, France.

${ }^{3}$ Université Paris-Est, Faculté de Médecine, Créteil, France. ${ }^{4}$ AP-HP, Hôpital Armand Trousseau, Service de Radiologie

Pédiatrique, Paris, France. ${ }^{5}$ Université Pierre et Marie Curie, Paris 6, Paris, France. ${ }^{6}$ AP-HP, Hôpital Armand Trousseau, Service d'Hémato-Oncologie Pédiatrique Registre des Histiocytoses Centre de Référence des Histiocytoses, Paris, France.

Correspondence: Ralph Epaud, Paediatric Dept, Centre Hospitalier Intercommunal, 40 Avenue de Verdun, 94000 Créteil, France. E-mail: ralph.epaud@chicreteil.fr

Received: Aug 092014 | Accepted after revision: Sept 222014 | First published online: Nov 132014

This article has been revised according to the erratum published in the February 2016 issue of the European Respiratory Journal.

Support statement: The French Histiocytosis registry is supported by grants from the Institut de Veille Sanitaire and INSERM. This project received constant and unlimited support from the Association Histiocytose France, a grant from the association "la petite maison dans la prairie" and a grant from the RMHE. This report was based on research from the Centre de Reference des Histiocytoses and was supported by the Société d'Hémato Immunologie Pédiatrique and the Société Française des Cancers de l'Enfant.

Conflict of interest: None declared.

Acknowledgements: The authors thank the patient and the family for their participation. The authors thank Abdellatif Tazi (Service de pneumologie, Hôpital Saint-Louis, Paris, France) for council.

\section{References}

1 Donadieu J, Chalard F, Jeziorski E. Medical management of Langerhans cell histiocytosis from diagnosis to treatment. Expert Opin Pharmacother 2012; 13: 1309-1322.

2 Kambouchner M, Basset F, Marchal J, et al. Three-dimensional characterization of pathologic lesions in pulmonary Langerhans cell histiocytosis. Am J Respir Crit Care Med 2002; 166: 1483-1490.

3 Tazi A, Soler P, Hance AJ. Adult pulmonary Langerhans' cell histiocytosis. Thorax 2000; 55: 405-416.

4 Dauriat G, Mal H, Thabut G, et al. Lung transplantation for pulmonary Langerhans' cell histiocytosis: a multicenter analysis. Transplantation 2006; 81: 746-750.

5 Lazor R, Etienne-Mastroianni B, Khouatra C, et al. Progressive diffuse pulmonary Langerhans cell histiocytosis improved by cladribine chemotherapy. Thorax 2009; 64: 274-275.

6 Lorillon G, Bergeron A, Detourmignies L, et al. Cladribine is effective against cystic pulmonary Langerhans cell histiocytosis. Am J Respir Crit Care Med 2012; 186: 930-932.

7 Georget-Bouquinet E, Madhi F, Delacourt C, et al. Manifestations pseudoneurologiques révélatrices d'une histiocytose langerhansienne [Inaugural trunk dystonia revealing Langerhans cell histiocytosis]. Arch Pediatr 2009; 16: 1021-1023.

8 Tazi A, Marc K, Dominique S, et al. Serial computed tomography and lung function testing in pulmonary Langerhans' cell histiocytosis. Eur Respir J 2012; 40: 905-912.

$9 \quad$ Dinwiddie R. The lung in multi-system disease. Paediatr Respir Rev 2000; 1: 58-63.

10 Saven A, Figueroa ML, Piro LD, et al. 2-chlorodeoxyadenosine to treat refractory histiocytosis x. $N$ Engl J Med 1993; 329: 734-735.

11 Weitzman S, Braier J, Donadieu J, et al. 2'-chlorodeoxyadenosine (2-CdA) as salvage therapy for Langerhans cell histiocytosis (LCH). Results of the LCH-S-98 protocol of the Histiocyte Society. Pediatr Blood Cancer 2009; 53: 1271-1276.

12 McClain KL. Drug therapy for the treatment of Langerhans cell histiocytosis. Expert Opin Pharmacother 2005; 6 : $2435-2441$. 